\title{
Bir ailede gelişen bruselloz olgularının değerlendirilmesi
}

\section{Evaluation of brucellosis cases within the same Family}

\section{Çiğdem Kader*, Ayşe Erbay}

Enfeksiyon Hastalıkları ve Klinik Mikrobiyoloji Anabilim Dalı (Dr. Ç. Kader, Dr. A. Erbay), Bozok Üniversitesi Tıp Fakültesi, TR-66200 Yozgat

\section{Özet}

Bruselloz hayvanlardan insanlara bulaşan ve gelişmekte olan ülkelerde endemik olarak görülen bir zoonozdur. Hayvancilıkla uğraşan kişilerde, kasaplarda, veterinerlerde, taze peynir yeme öyküsü olanlarda ve laboratuvar çalışanlarında görülmektedir. Hayvancılıkla uğraşan bir ailede gelişen bruselloz olgularının epidemiyolojik, klinik ve laboratuvar bulguları bu makalede incelendi. Tüm olgularda ateş, sedimentasyon yüksekliği, C-reaktif protein yüksekliği ve artralji mevcut idi. Hastaların yakınmalarının süresi 7-21 gün arasında değişmekteydi. Bir hastada L3-L4 düzeyinde spondilodiskit mevcut idi. Dört olgu rifampisin ve doksisiklin tedavisi ile iyileşti, olgulardan birisi (spondilodiskit) ise kotrimaksazol ve rifampisin ile tedavi edildi. Tüm olgularda medikal tedavi ile tam iyileşme sağlandı ve relaps izlenmedi. Bu olgular brusellozun, hastalık taşıyan hayvanlardan, bu hayvanlara bakım veren kişilerin tümüne bulaşabileceğini vurgulamak amacıyla sunulmuştur.

Anahtar sözcükler: Bruselloz, aile bireyleri, bulaş

\begin{abstract}
Brucellosis is a zoonosis transmitted from animals to humans and endemically seen in developing countries. It is seen among veterinarians, laboratory workers and ones who deal with animal husbandry, butchery, have history of eating fresh cheese. In this article, epidemiological, clinical and laboratory findings of brucellosis cases developed in a family dealing with animal husbandry were evaluated. In all cases; there were fever, elevated erythrocyte sedimentation rate, increased C-reactive protein levels, and arthralgia. Duration of the complaints were ranging between 7 to 21 days. One of the cases had spondylodiscitis at level of L3-L4. Four of the cases were treated with rifampicin and doxycycline, one cese with spondylodiscitis was treated with the co-trimoxazole and rifampicine. Complete cure was obtained with medical treatment in all patients, and relapse wasn't observed in any of them. These cases were presented in order to emphasize that brucellosis might be transmitted from bacteria-carrying animals to all caregivers dealing with them.
\end{abstract}

Keywords: Brucellosis, family members, transmission

Geliş tarihi/Received: 05 Mayıs 2014; Kabul tarihi/Accepted: 09 Aralık 2014

\author{
*İletişim adresi: \\ Dr. Çiğdem Kader, Enfeksiyon Hastalıkları ve Klinik Mikrobiyoloji Anabilim Dalı, Bozok \\ Üniversitesi Tıp Fakültesi, TR-66200 Yozgat. E-posta: dr_cigdemtr@yahoo.com
}

\section{Giriş}

Bruselloz, insanları ve koyun, keçi, inek, deve gibi birçok evcil hayvanı etkileyen dünyada yaygın görülen bir zoonozdur [1]. Gelişmiş ülkelerde hayvanlar arasında tamamen eradike edilmiş olmakla birlikte, ülkemizde Orta Anadolu, Doğu ve Güneydoğu Anadolu başta olmak üzere hala yaygın olarak görülmektedir [2]. Sindirim sistemi, infekte dokularla direkt temas ve inhalasyon olmak üzere üç ana bulaş yolu vardır. Ülkemizde en sı1k bulaş yolu çiğ sütten yapılmış peynir, krema ve yağ tüketimidir. Her yaş ve cinsiyette görülebilir ancak en sı1k 15-35 yaş arasında karşımıza çıkmaktadır [3]. 
İnkübasyon süresi iki-üç haftadır. Bu süreyi takiben ateş, üşüme, titreme, halsizlik, miyalji, artralji, baş ağrısı gibi özgül olmayan semptomlar ortaya çıkar. Bu makalede hayvancılıkla uğraşan aynı evde yaşayan bir ailede gelişen bruselloz olgularının epidemiyolojik klinik ve laboratuvar bulguları incelendi. Hastalığın hayvanlardan, bu hayvanlara bakım veren aynı evde yaşayan aile bireylerine bulaşabileceğini vurgulamak amaciyla bu makale sunulmuştur.

\section{Olgu sunumu}

\section{Olgu 1}

Kırk iki yaşında erkek hasta, polikliniğimize 15 gündür devam eden ateş yüksekliği, halsizlik, iştahsızlık, gece terlemesi, eklem ağrıları şikayetleriyle başvurdu. Öyküsünde hayvancılıkla uğraştığı, Doğu Anadolu Bölgesi'nden 82 tane yeni küçükbaş hayvan satın aldığı ve hayvanlarından 23 tanesinin düşük yapmış olduğu ve brusella yönünden aşılanmamış olduğu öğrenildi. Fizik muayenesinde; ateş $38,2{ }^{\circ} \mathrm{C}$, kan basıncı 110/80 mmHg, nabız 77/dak. ölçüldü.

\section{olgu 2}

İlk olgunun eşi olan 36 yaşındaki kadın hasta, polikliniğimize bir haftadır olan ateş yüksekliği, gece terlemesi, bel ağrısı şikayetleri ile başvurdu. Öyküsünde hayvancılıkla uğraşan eşine yardımcı olduğu, çiğ süt ve süt ürünleri tüketme hikayesi olduğu öğrenildi. Fizik muayenesinde; ateş $37,8^{\circ} \mathrm{C}$, kan basınc1 $120 / 70 \mathrm{mmHg}$, nabız 80/dak. ölçüldü. Sakroiliak eklem muayene testleri negatif olarak değerlendirildi. Lumbosakral vertebra ve sakroiliak eklem direkt grafisinde patolojik bulgu saptanmadi.

\section{olgu 3}

İlk olgunun kardeşi olan 38 yaşındaki erkek hasta polikliniğimize 10 gündür olan ateş yüksekliği, gece terlemesi, halsizlik, iştahsızlık ve eklem ağrıları ile başvurdu. Öyküsünde abisi ile birlikte hayvancılıkla uğraştığı ve, yeni almış oldukları hayvanlarının büyük bir kısmının düşük yapmış olduğu öğrenildi. Fizik muayenesinde; ateş $38,2{ }^{\circ} \mathrm{C}$, kan basınc1 120/70 mmHg, nabız: 78/dak. ölçüldü.

\section{Olgu 4}

İlk olgunun kardeşi olan 40 yaşındaki kadın hasta üç haftadır olan ateş yüksekliği ve gece terlemesi şikayetleri ile polikliniğimize başvurdu. Öyküsünde abisinin bulunduğu çiftlikte hayvancılıkla uğraştığı ve çıplak elle hayvanlardan süt sağdığı öğrenildi. Fizik muayenesinde; ateş $37,9^{\circ} \mathrm{C}$, kan basıncı $120 / 70 \mathrm{mmHg}$, nabız 77/dak. ölçüldü.

\section{Olgu 5}

İlk olgunun annesi olan 66 yaşındaki kadın hasta; polikliniğimize bir aydır devam eden, yüksek ateş, bel ağrısı, iştahsızlık ve gece terlemesi şikayetleri ile başvurdu. Özgeçmişinde diabetes Mellitus ve hipertansiyon tanıları olan hastanın öyküsünde zaman zaman hayvanlardan çıplak el ile süt sağdığ kan basıncı 130/80 mmHg, nabız 78/dak. ölçüldü. Kontrastlı Lomber Manyetik Rezonans Görüntüleme tetkiki sonucunda L3-L4 vertebra düzeyinde spondilodiskit ile uyumlu lezyon tespit edildi.

Olguların klinik ve laboratuvar özellikleri Tablo-1'de özetlenmiştir. Olguların tamamında medikal tedavi ile tam iyileşme sağlandı ve tedavi bitiminden itibaren altı aylık sürede relaps izlenmedi. 
Tablo 1. Olguların klinik ve laboratuvar özellikleri.

\begin{tabular}{llllll}
\hline Değişken & Olgu 1 & Olgu 2 & Olgu 3 & Olgu 4 & Olgu 5 \\
\hline Cinsiyet & Erkek & Kadın & Erkek & Kadın & Kadın \\
\hline Yaş & 42 & 36 & 38 & 40 & 60 \\
Ateş & $38,2{ }^{\circ} \mathrm{C}$ & $37,8^{\circ} \mathrm{C}$ & $38,2{ }^{\circ} \mathrm{C}$ & $37,9{ }^{\circ} \mathrm{C}$ & $38,5{ }^{\circ} \mathrm{C}$ \\
Lökosit & $7200 / \mathrm{mm}^{3}$ & $11800 / \mathrm{mm}^{3}$ & $8320 / \mathrm{mm}^{3}$ & $8800 / \mathrm{mm}^{3}$ & $9750 / \mathrm{mm}^{3}$ \\
Hemoglobin & $13 \mathrm{~g} / \mathrm{dL}$ & $14 \mathrm{~g} / \mathrm{dL}$ & $15,3 \mathrm{~g} / \mathrm{dL}$ & $13,5 \mathrm{~g} / \mathrm{dL}$ & $11.2 \mathrm{~g} / \mathrm{dL}$ \\
CRP & $18 \mathrm{mg} / \mathrm{dL}$ & $21 \mathrm{mg} / \mathrm{dL}$ & $15 \mathrm{mg} / \mathrm{dL}$ & $24 \mathrm{mg} / \mathrm{dL}$ & $20,9 \mathrm{mg} / \mathrm{dL}$ \\
Sedimentasyon & $36 \mathrm{~mm} / \mathrm{saat}$ & $41 \mathrm{~mm} / \mathrm{saat}$ & $32 \mathrm{~mm} / \mathrm{saat}$ & $28 \mathrm{~mm} / \mathrm{saat}$ & $92 \mathrm{~mm} / \mathrm{saat}$ \\
ALT & $50 \mathrm{U} / \mathrm{L}$ & $25 \mathrm{U} / \mathrm{L}$ & $22 \mathrm{U} / \mathrm{L}$ & $18 \mathrm{U} / \mathrm{L}$ & $28 \mathrm{U} / \mathrm{L}$ \\
AST & $72 \mathrm{U} / \mathrm{L}$ & $18 \mathrm{U} / \mathrm{L}$ & $21 \mathrm{U} / \mathrm{L}$ & $22 \mathrm{U} / \mathrm{L}$ & $10 \mathrm{U} / \mathrm{L}$ \\
STA & $1 / 1280$ & $1 / 640$ & $1 / 640$ & $1 / 1280$ & $1 / 1280$ \\
Tedavi (süre) & Rifampisin & Rifampisin & Rifampisin & Rifampisin & Sulfametoksazol 800 \\
& $600 \mathrm{mg} /$ gün & $600 \mathrm{mg} /$ gün & $600 \mathrm{mg} /$ gün & $600 \mathrm{mg} /$ gün & $\mathrm{mg} /$ gün + Trimetoprim \\
& + Doksisiklin & + Doksisiklin & + Doksisiklin & + Doksisiklin & $160 \mathrm{mg} /$ gün ve \\
& $200 \mathrm{mg} /$ gün & $200 \mathrm{mg} /$ gün & $200 \mathrm{mg} /$ gün & $200 \mathrm{mg} /$ gün & Rifampisin $600 \mathrm{mg} /$ gün \\
& $(6 \mathrm{hafta})$ & $(6 \mathrm{hafta})$ & $(6 \mathrm{hafta})$ & $(6 \mathrm{hafta})$ & (9 ay)
\end{tabular}

Referans değerler: CRP: (0-5 mg/L), sedimentasyon: 0-30 mm/saat, hemoglobin: $12-18,1 \mathrm{~g} / \mathrm{dL}$, ALT: 0-45 IU/L, AST: 0-35 IU/L ,STA (standart tüp aglütinasyon testi)

\section{Tartışma}

Bruselloz, hayvanlardan insanlara bulaşan, hafif belirtilerden ağır klinik tablolara kadar değişebilen, akut veya kronik seyirli olabilen, belirti ve bulguları spesifik olmayan ve birçok hastalığı taklit edebilen sistemik bir enfeksiyon hastalığıdır. Ülkemizde ve gelişmekte olan ülkelerde yaygın görülen, ekonomik kayıplara neden olması ve gıda güvenliğini doğrudan etkilemesi nedeniyle önemli bir halk sağlığı sorunu oluşturan bir zoonozdur [4]. Türkiye'de bruselloz yaygınlığı bölgelere göre farklılık göstermektedir. Ülkemizde en az bildirim Karadeniz Bölgesi'nden yapılırken, olgular daha çok hayvancılığın yaygın olarak yapıldığı Doğu Anadolu ve İç Anadolu Bölgesi'nden bildirilmektedir. Özellikle hayvan yetiştiricileri, süt ve süt ürünleriyle uğraşanlar, veteriner hekimler, kasaplar, mezbaha işçileri ve laboratuvar çalışanlarının mesleki risk altında olduğu bilinmektedir. İnsanlarda bulaş, insandan insana, kontamine çevreden bulaş, meslek hastalığı olarak bulaş ve gıda kaynaklı bulaş başlıkları altında dört grupta toplanabilir. Kırsal kesimde brusellozun esas bulaş yolu kontamine gıdaların tüketilmesidir. Kaynatılmadan hazırlanan süt ve süt ürünlerinin tüketilmesi, toplumda enfeksiyonun en önemli kaynağıdır [5]. Bizim olgularımız; hayvancılıkla uğraşan aile bireylerinden oluşmaktaydı ve süt ve süt ürünleri tüketme öyküleri mevcut idi. Olgu 1 hayvancılıkla uğraşmaktaydı ve Doğu Anadolu Bölgesi'nden yeni almış olduğu hayvanlarının aşılanmamış olduğunu ifade ederek, çıplak elle hayvanlarına dokunarak süt sağdığını ve hayvanlarının kan ve vücut sıvılarına temas ettiğini ifade etmekteydi. Olgu 2 eşine hayvancılık işlerinde yardım ederek çıplak elle temas öyküsü olmasının yanında aynı zamanda süt ve süt ürünlerini gastrointestinal sistem yolu ile tüketme öyküsüne de sahip idi. Olgu 3, Olgu 4 ve Olgu 5'te, Olgu 1 ile aynı şekilde çıplak el ile hayvanlara temas öyküsüne sahiplerdi.

Brusellozda eklem ağrısı, ateş, halsizlik, terleme ve bel ağrısı en sık rastlanan semptomlardır [6]. Bizim olgularımızda sık görülen semptomlar benzer şekilde saptanmıştır. Başlangıç semptomları sessiz veya akut olabilir. Semptomların süresine göre hastalık akut, subakut, kronik ve lokalize (fokal) olmak üzere dört ana formda sinıflandırılmaktadır. Hastalık süresi sekiz haftadan az ise akut bruselloz, semptomların süresi 8-52 hafta arasinda ise subakut bruselloz, bir yıldan uzun ise kronik bruselloz olarak adlandırılmaktadır. Herhangi bir organ tutulumunda ise hastalık fokal veya lokalize olarak tanımlanmaktadır. Fokal hastalık akut formun komplikasyonu olarak görülebileceği gibi, kronik brusellozun klinik tablosuna da eşlik edebilir [4]. Bizim olgularımızın hepsi akut bruselloz formu olarak karşımıza çıkmışlardı. Olgu-5; akut brusellozun spondilodiskit ile komplike olmuş olan lokalize/fokal formu olarak değerlendirildi. 
Brusellozda en sık kas-iskelet sistemi komplikasyonları görülmekle birlikte farklı çalışmalarda bu oran \%19-69 arasında değişmektedir [7-10].

Dünya Sağlık Örgütü tarafında bruselloz için önerilen tedavi, altı hafta süreyle doksisiklin $200 \mathrm{mg} /$ gün ve rifampisin 600-900 mg/gün ya da altı hafta tetrasikllin veya doksisiklin ve üç hafta süreyle streptomisin uygulamasıdır [7]. Bizim dört olgumuzda da rifampisin + doksisiklin tedavisine yanıt alınmıştır. Bir olgumuz (Olgu-5) spondilodiskit tanısı ile izlenmiş ve doksisiklin tedavisini tolere edemediği için dokuz ay süre ile sulfametoksazol $(800 \mathrm{mg} /$ gün $)+$ trimetoprim $(160 \mathrm{mg} /$ gün $)$ ve rifampisin $(600 \mathrm{mg} / \mathrm{gün})$ ile tedavi edilmiştir. Aygen ve ark. [8] Çalışmalarında en düşük relaps oranının doksisiklin ve rifampisin kombinasyonunda olduğu bildirilmiştir. Brusellozda relaps oranları çalışmalara göre değişmekler birlikte ortalama \%5-8'dir [13,14]. Bizim olgularımızda tedavi ile tam iyileşme görülmüş ve tedavi bitiminden itibaren altı aylık süre içerisinde relaps izlenmemiştir.

İnsanlara, bruselloz; enfekte hayvanlarla direkt temas veya dolaylı temas ile bulaşır. $\mathrm{Bu}$ nedenle insanlarda enfeksiyonun önlenmesi ve kontrolü de bu temas zincirinin kırılması ve hayvan rezervuarlarında enfeksiyonun kontrolü ve eliminasyonuna bağlıdır. Hayvanlar için etkili canlı bakteri aşıları; B. abortus (suş 19) ve B.melitensis (suş Rev-1) türlerine karşı hazırlanmıştır. B. suis veya B. canis'e karşı geliştirilmiş aşı yoktur. Bu aşılar ülkemizde de uygulanmaktadır. Bu aşılar insanlara uygulanmaz. Bizim olgularımızın Doğu Anadolu Bölgesi’nden almış oldukları hayvanlarının aşılı olmadığı öğrenildi. Aynı zamanda hayvanlarının düşük öyküleri olduğu bilinmekteydi. Aile hayvancılığında, bütün aile bireylerinin hayvanlarla yakın teması vardır. Bulaşın önlenmesinde; temasın azaltılması, kontamine materyallerle bulaşın önlenmesi, bu aile bireylerinin eğitilmesi önemlidir. Ayrıca aile bireylerinin yaşam alanları ile hayvan barınaklarının uygun şekilde yapılandırılması bulaşın önlenmesinde önemlidir. İster aile hayvancılığında olsun, ister çiftlik hayvancılı̆̆ında, kontamine hayvan atıklarının yok edilmesi, çevre dezenfeksiyonu usulune uygun yapılmalıdır. Risk gruplarının kontamine materyalin özelliğine göre; su geçirmeyen eldiven, yüz koruyucu maske, göz koruyucu gözlük, su geçirmeyen önlük, aerosol oluşturan bir iş ise respiratör kullanmaları sağlanmalıdır. İş bittikten sonra eller mutlaka yıkanmalıdır. Eğer vücudun her hangi bir yerine kontamine materyal bulaştı ise, bol su ile yıkanmalı veya hemen bol su ile banyo yapılmalıdır. Gözlere herhangi bir materyal sıçradığında yine konjunktivalar bol su ile yıkanmalıdır [4].

Bizim olgularımız aynı aileden olan ve aynı evde yaşamakta olan aile hayvancılığı ile uğraşan hastalardan oluşmaktaydı. Ortak özellikleri, hasta hayvanların bakımıyla uğraşmak, çıplak elle hayvanlardan süt sağmak ve bu hayvanlardan elde ettikleri süt ve süt ürünlerini tüketmekti. Bu olgular brusellozun, hastalığı olan hayvanlardan; bu hayvanlara bakım veren aile hayvancıllğı ile uğraşan kişilerin tümüne bulaşabileceğini vurgulamak amaciyla sunuldu.

\section{Kaynaklar}

1. Shimol BS, Dukhan L, Belmaker I, Bardenstein S, Sibirsky D, Barrett C. Human Brusellosis Outbreak Acquired through Camel Milk Ingestion in Southern Israel. IMAJ vol 14 August 2012: 475-8.

2. Demirdal T, Demirtürk N, Demirbaş M. Brusella Orşiti: Aynı aileden iki olgu sunumu. ANKEM Derg 2004; 18: 117-9.

3. Aktuğ Demir N, Ural O. Komplike Olmayan Akut Brusellozlu 83 olgunun İrdelenmesi. Flora 2010; 15: 132-8.

4. Zoonotik hastalıklar hizmet içi eğitim modülü. Erişim tarihi: 23 Temmuz 2013 http://sbu.saglik.gov.tr/Ekutuphane/kitaplar/Zoonotik\%20Hastaliklar\%20Katilim ci\%20Kitabi.pdf

5. Biten Güven G, Güven T, Güney T, Seyrek A. Elazığ Bölgesi'nde riskli meslek gruplarında bruselloz seroprevalans1. Flora 2012; 17: 62-7. 
6. Gonen I, Sozen H, Kaya O, Unal O, Guloglu G, Akcam FZ. Brusellosis: Evaluation of 201 cases in an endemic area of mediterranean Basin. Acta Medica Mediterranean 2014, 30: 121.

7. Demiroğlu Z, Turunç T, Alışkan H, Çolakoğlu Ş, Arslan H. Bruselloz: 151 Olgunun Klinik, Laboratuvar ve Epidemiyolojik Özelliklerinin Retrospektif Değerlendirilmesi. Mikrobiyol Bül 2007; 41: 517-27.

8. Aygen B, Doğanay $\mathrm{M}$, Sümerkan B, Yıldız O, Kayabaş U. Clinical manisfestations, complications and treatment of brusellosis: A retrospective evaluation of 480 patients. Medecine et Maladies Infectieuses 2002; 32: 485-93.

9. Colmenero JD, Reguera JM, Martos F. Complications associated with Brucella melitensis infection; a study of 530 cases. Medicine (Baltimore) 1996; 74: 195211.

10. Taşova Y, Saltoğlu N, Şahin G, Aksu HS. Osteoarthricular involvement of brucellosis in Turkey. Clin Rheumatol 1999; 18: 214-9.

11. Gür A, Geyik MF, Dikici B. Complications of brucellosis in different age groups: A study of 283 cases in southern Anatolia of Turkey. Yonsei Medical J 2003; 44: 33-44.

12. Demirdağ K, Özden M, Kalkan A, Çelik I, Kılıç SS: Bruselloz; 72 olgunun incelenmesi. Flora 2005; 10: 185-90.

13. Mantur BG, Amarnath SK, Shinde RS. Review of Clinical and laboratory features of human bruellosis. Indian Journal of Medical Microbiology 2007; 25: 188-202.

14. Skalksy K, Yahav D, Bishara J, Pitlik S, Leibovici L, Paul M. Treatment of human brucellosis: Systematic review and meta-analysisnof randomised controllend trials. BMJ 2008; 336: 701-4. 